Journal of Bangladesh Chemical Society, Vol. 24(2), 221-225, 2011.

DOI: 10.3329/jbcs.v24i2.9712

\title{
COMPARATIVE STUDY OF BANGLADESH BARAPUKURIA COAL WITH THOSE OF VARIOUS OTHER COUNTRIES
}

\author{
S. SAFIULLAH ${ }^{1 *}$, M. R. R. KHAN ${ }^{2}$ AND M. A. SABUR ${ }^{1}$ \\ ${ }^{I}$ Department of Chemistry, Jahangirnagar University, Savar, Dhaka, Bangladesh \\ ${ }^{2}$ Department of Chemistry, Siddeshwari Girls College, Dhaka, Bangladesh
}

\begin{abstract}
Comparative study of the qualities of the Bangladeshi, Indian, Australian and Indonesian coals was made in terms of coking properties, calorific value, sulfur content, moisture, ash, volatile matters and carbon content. Bangladesh Barapukuria coal was found to be the best of all the coal samples with a carbon content of $56.47 \%$ and other qualities Bangladeshi coal clearly indicate that it is also suitable for value added utilization.
\end{abstract}

\section{Introduction}

Coal is a very complex heterogeneous mixture of organic compounds and minerals. More specifically, it is a combustible solid, usually stratified, which originated from the accumulation, burial and compaction of partially decomposed vegetation over the geologic ages ${ }^{1}$. It is an important energy source of the nature and is primarily used as a solid fuel to produce electricity and heat through combustion. The efficiency of the process utilized for the development of this resource requires an adequate knowledge of the physico-chemical characteristics of $\mathrm{coal}^{2}$.

The discovery of Bangladesh Barapukuria coal provides a major opportunity in studying the coal in some details. The techno-economical feasibility as well as the precursor states for the graphitization of this coal has already been studied ${ }^{3-5}$. Yet, no work has been carried out on the comparative study of Bangladesh Barapukuria coal with those of various other countries.

Coals are classified into lignite, sub-bituminous, bituminous, anthracite and graphite types mainly on the basis of fixed carbon and gross calorific value. Lignite coal is more soil like than a rock and tends to disintegrate when exposed to weather. The calorific value of lignite coal is about 5800 to $7000 \mathrm{Btu} / \mathrm{Ib}$. Sub-bituminous coal is black and its calorific value varies from 8300 to $11500 \mathrm{Btu} / \mathrm{Ib}$ and that of bituminous coal falls within the range 12000 to $15000 \mathrm{Btu} / \mathrm{Ib}^{6}$. It is the best quality coal in the world and most widely used $^{7}$. Anthracite is very hard, black and lustrous. It is low in sulfur, highest in fixed carbon and lowest in volatile matter among all types of coal.

Bangladesh occupies a major part of the Bengal basin, north western part of the country is filled with very thick sediments. The geological history of Bangladesh is complex. In the centre of the country within Bengal basin, an immense thickness of sedimentary formations rest on the ancient igneous and metamorphic Precambrian Arcean basement ${ }^{8}$. In the north western part of the country (out side the Bengal basin), the basement is present at much shallower depth.

* Author to whom correspondence should be made 
Shelf or saddle of Arcean rocks is covered directly by late tertiary sediments. These mostly continental sediments were deposited within the ancient southern super continent of Gondwanaland when the Indian sub plate was directly attached to southern Africa, Antarctica and Australia.

Bangladesh uses considerable amount of coal for various industries such as steel foundries, cocking coal and brick manufacture, home cooking etc. Most of these coals are usually imported. Therefore, it is necessary for government agencies and importers to have a comprehensive understanding of the coal being imported from various sources. Also, recently power generation has been started with local Barapukuria coal. Present study, therefore aims at making a comprehensive, comparative study of the qualities of Bangladeshi coal with other coals imported from various countries.

\section{Experimental}

Coal samples collected from various mines of the world such as Bangladesh (Barapukuria), India (Tamabil, Borochara, Tirap and Dhanbad), Australia (New South Wales) and Indonesia (Sebuku) were ground to a specific size and air dried to moisture content in equilibrium with the laboratory environment and were preserved in air-tight polythene bags prior to analysis. Various properties such as coking properties in terms of free swelling index (FSI), calorific value (CV), sulfur content (S), moisture (M), ash (A), volatile matter (VM) and fixed carbon (FC) of all the coal samples were determined according to American Society for Testing Materials (ASTM) ${ }^{9}$.

The free swelling index of coal is a measure of the increase in volume when it is heated under prescribed condition. Calorific value was determined by combusting a specific amount of sample in pure oxygen at $30 \mathrm{kp} / \mathrm{cm}^{2}$ taking in a calibrated adiabatic bomb calorimeter (C 400, Germany) under controlled condition. The thermal capacity of the adiabatic system had been evaluated by the combustion of a reference substance such as benzoic acid under the same experimental condition. Percentage of sulfur content was determined gravimetrically as $\mathrm{BaSO}_{4}$ precipitation by analyzing the washings obtained from the oxygen-bomb calorimeter (C 400, Germany). Percentage of moisture was obtained by heating a specific amount of air dried substance in an oven at $105{ }^{\circ} \mathrm{C}$ and considering the weight loss. For ash determination, dried coal samples obtained from the moisture determination was further heated in presence of oxygen at 700 to $750{ }^{\circ} \mathrm{C}$ taking in a muffle furnace (Germany) for around three hours. Percentage of ash was calculated from the weight difference, before and after heating. Specific amount of coal sample taking in a platinum crucible was heated in absence of oxygen at around $950{ }^{\circ} \mathrm{C}$ for a few minutes. The percentage of weight loss minus the percentage of moisture, gives the percentage of volatile matter. No specific experiment was carried out for the estimation of fixed carbon. It was obtained by subtracting the summation of the percentages of moisture, ash and volatile matter from 100. Except FSI and Calorific value, all the properties were measured several times. The experiments were carried out in the 
Department of Chemistry, Jahangirnagar University, Savar, Dhaka, Bangladesh and in the laboratory of Geological Survey of Bangladesh.

\section{Results and Discussion}

There are many compositional differences between the coals mined from the different coal deposits worldwide. The different types of coal are most usually classified by rank which depends upon the degree of transformation from the original source (i.e., decayed plants) and is therefore a measure of a coal's age. Results obtained from the analyses of various properties of the coals are given in Table 1.

Table 1. Various properties of coal samples collected from various places

\begin{tabular}{|c|c|c|c|c|c|c|c|}
\hline $\begin{array}{c}\text { Sampling } \\
\text { location }\end{array}$ & $\begin{array}{c}\text { FSI } \\
\text { value }\end{array}$ & $\begin{array}{c}\text { CV } \\
(\mathrm{Btu} / \mathrm{Ib})\end{array}$ & $\%$ of S & \% of M & $\%$ of Ash & \% of VM & $\begin{array}{c}\% \text { of } \\
\text { FC }\end{array}$ \\
\hline Bangladesh & 5.0 & 12002 & $0.67 \pm 0.04$ & $2.73 \pm 0.10$ & $12.10 \pm 1.91$ & $28.70 \pm 1.31$ & 56.47 \\
\hline $\begin{array}{c}\text { India } \\
\text { (Tamabil) }\end{array}$ & 2.0 & 7312 & $4.34 \pm 1.30$ & $1.32 \pm 0.20$ & $23.82 \pm 2.01$ & $34.78 \pm 2.69$ & 40.08 \\
\hline $\begin{array}{c}\text { India } \\
\text { (Borochara) }\end{array}$ & 2.5 & 9204 & $1.62 \pm 0.24$ & $0.98 \pm 0.12$ & $5.67 \pm 1.34$ & $42.25 \pm 2.35$ & 51.10 \\
\hline India (Tirap) & 4.5 & 11873 & $1.34 \pm 0.08$ & $4.30 \pm 0.90$ & $7.71 \pm 1.56$ & $32.24 \pm 1.69$ & 55.75 \\
\hline $\begin{array}{c}\text { India } \\
\text { (Dhanbad) }\end{array}$ & 3.5 & 8023 & $2.53 \pm 0.28$ & $7.50 \pm 1.01$ & $15.60 \pm 1.40$ & $31.50 \pm 1.89$ & 45.40 \\
\hline Australia & 4.5 & 11902 & $0.63 \pm 0.08$ & $2.40 \pm 0.20$ & $13.60 \pm 1.33$ & $29.80 \pm 1.89$ & 54.20 \\
\hline Indonesia & 2.0 & 7038 & $2.32 \pm 0.50$ & $7.20 \pm 1.68$ & $13.18 \pm 1.84$ & $38.04 \pm 2.28$ & 41.58 \\
\hline
\end{tabular}

Coking properties cannot be measured directly and is expressed in terms of free swelling index (FSI). The values for the lower rank of coals are normally less than those for bituminous coals, while anthracite does not fuse and shows no swelling value ${ }^{1}$. The FSI of bituminous coals generally increases with an increase in rank. Medium volatile coals are expected to have good coking properties. From the study, it is seen that coking properties of Bangladeshi coal is the best among all the coal samples as indicated by the FSI values. The value ranges from 2.0 to 5.0 for the collected samples where the highest value was observed for the Barapukuria coal.

Calorific value is the most important quality for coal that is to be used for heating purposes. This value is used to classify coals to bituminous, sub-bituminous, lignite etc. and is also used in estimating resources. As per gross calorific value, India (Tamabil), India (Borochara), India (Dhanbad) and Indonesian coals are classified as sub-bituminous type whereas Bangladesh (Barapukuria), India (Triap) and Australian coals are of bituminous type.

Sulfur is present in coal either as organically bound sulfur or as inorganic sulfur. Typically sulfur content varies up to $10 \%^{1}$. In combustion process, sulfur combines with oxygen to form sulfur oxides, which is environmentally harmful and is responsible for acid rain. In Bangladesh, rain is sometimes contaminated by $\mathrm{SO}_{2}$ emitted by burning of 
coal in India ${ }^{10}$. In upper atmosphere, $\mathrm{SO}_{2}$ combines with water vapour to form sulfuric acid. High sulfur content lowers the quality of coke for iron and steel products and is not suitable for metallurgical processing. Sulfur content of Bangladesh (Barapukuria) and Australian coals are very low and suitable for combustion purpose without any environmental hazard.

The moisture content is determined by the mass loss that a coal sample undergoes after it has been heated to $105{ }^{\circ} \mathrm{C}$ under $\mathrm{N}_{2}$ atmosphere. The moisture content measured represents water that may be physically or chemically bound in the coal with the exception of mineral hydrates. The percentage of water present in various types of coals varies with the rank of coal. Anthracite has the least quantity of moisture, then bituminous, then subbituminous, and lignite has the most. Higher the moisture content, lower is the energy value of coal ${ }^{1}$. In our study, the moisture content ranges from 2.0 to $15.0 \%$. Bangladesh (Barapukuria) coal is considered to have lower moisture content $(2.73 \%)$ and hence have higher energy value.

Coal ash is the residue remaining after the combustion of coal under specified conditions. The ash content does not directly correspond to the mineral content of the coal sample because the minerals may have undergone thermal decomposition (e.g., loss of $\mathrm{CO}_{2}$ from carbonates) or chemical change (e.g., the oxidation of iron pyrite to iron oxide) ${ }^{11}$. Ash content, as high as $50.0 \%$ has been reported but 5.0 to $15.0 \%$ is more typical ${ }^{1}$. In the present work, it was observed that percentage of ash of Bangladesh Barapukuria coal is quite low with a value of $12.10 \%$ as compared to that of Indonesia and India (Borochara) with a value of 38.04 and $42.25 \%$ respectively.

Value of volatile matter gives an indication for the amount of smoke that may be emitted from the furnace and is also important in the selection for coking coal ${ }^{1}$. Volatile matter generally varies from 8.8 to $45.5 \%$ by weight ${ }^{12}$ and these volatiles include lighter aromatic hydrocarbons, complex oil tar, phenols and other chemicals. Lignite and bituminous coals have comparatively high volatile matter contents than the anthracite coals. Volatile matter content varies with the rank of the coal. Anthracite coal has the lowest volatile matter content (typically $2-12 \%$ ). Bituminous, subbituminous and lignite coals yield higher values, 15-45\%, 28-45\%, and 24-32\%, respectively ${ }^{11}$. Bangladesh Barapukuria coal falls under bituminous type.

The value of fixed carbon is obtained by subtracting the sum of the percentages of moisture, ash and volatile matter from 100. It is a measure of the solid combustible material that remains after the volatile matter in coal has been removed. For this reason, it is also used as an indication of the yield of coke in the coking process. The fixed carbon content of coal is the highest for anthracite type, 75-85\%, and lowest for lignite 25-30\%. Bituminous and subbituminous coal yield intermediate results, 50-70\% and 30-57\%, respectively ${ }^{13}$. The value of fixed carbon is seen to be highest for Barapukuria coal $(56.47 \%)$ whereas lowest for India (Tamabil) with a value of $40.08 \%$. The percentage of fixed carbon in the coals of Barapukuria, Australia and India (Borochara) were observed almost same. 


\section{Concluding Remarks}

The analysis reveals that the coal of Bangladesh (Barapukuria), Australia and India (Tirap) are of higher rank bituminous type whereas the coal of India (Tamabil, Borochara and Dhanbad) and Indonesia are of sub-bituminous type. From the foregoing results it is clear that Bangladesh (Barapukuria) coal is best amongst seven coal samples collected from Bangladesh, India, Australia and Indonesia, in terms of coking quality, usage for metallurgical purposes and heat values. Considering these qualities, Bangladesh (Barapukuria) coal should also be used for the production of value added products such as coke and high carbon content materials.

\section{References}

1. R. K. Hessley, J. W. Reasoner and J. T. Riley, Coal Science, an Introduction to Chemistry and Utilization, John Willy \& Sons, New York, USA, 1986.

2. J. Poddar and S. Majumder, Thermochim. Acta., 2001, 372, 113.

3. J. Poddar, T. Hossain and Kh. M. Mannan, Thermochim. Acta., 1995, 255, 211.

4. J. Poddar and T. Hossain, Thermochim. Acta., 1996, 284, 279.

5. J. Poddar and T. Hossain, J. Bang. Acad. Science, 1998, 22, 71

6. M. L. Jenson and A. M. Bateman, Economic mineral deposits, John Wiley \& Co., New York, 1981, 593.

7. B. Imam, Energy Resourses of Bangladesh, ( $1^{\text {st }}$ edition $)$, University Grant Commission of Bangladesh, 2005, 180.

8. Wardell Armstrong, Techno-Economic Feasibility Study of Barapukuria CoalProject (unpubl), Dinaajpur, Bangladesh, 1991.

9. Annual Book of ASTM Standards, 1984, 05.05.

10. S. Safiullah, J. U. Ahmad, Proceedings of Asian Seminar on Acid Rain, Taipei, China, 1993, $3^{\text {rd }}$ CAAP.

11. C. J. Donahue and E. A. Rais, Journal of Chemical Education, 2009, 86, 222.

12. L. D. Smoth, and P. J. Smith, Coal Combustion and Gasification, Plenum Press, New York, 1985, 16.

13. J. G. Speight, Handbook of Coal Analysis, John Wiley and Sons: Hoboken, NJ, 2005, Chapter 3. 